\title{
Halomonas xinjiangensis sp. nov., a halotolerant bacterium isolated from a salt lake
}

Correspondence
Li-Li Zhang
zhang63lyly@yahoo.com.cn

The family Halomonadaceae currently includes four genera of halophilic bacteria, Halomonas, Chromohalobacter, Cobetia and Modicisalibacter, and three genera of nonhalophilic bacteria, Carnimonas, Halotalea and Zymobacter (Franzmann et al., 1988; Ventosa et al., 1989; Okamoto et al., 1993; Dobson \& Franzmann, 1996; Garriga et al., 1998; Arahal et al., 2002, 2007; Ntougias et al., 2007; Ben Ali Gam et al., 2007). The genus Halomonas was proposed by Vreeland et al. (1980), with Halomonas elongata as the type species. At the time of writing, the genus Halomonas contained the greatest number of species (54 species with validly published names; http://www.bacterio.cict.fr/ $\mathrm{h} / \mathrm{halomonas.html)}$ of all genera in the family Halomonadaceae.

The GenBank/EMBL/DDBJ accession number for the $16 \mathrm{~S}$ rRNA gene sequence of strain TRM $0175^{\top}$ is EU822512.

Phylogenetic trees based on maximum-parsimony and maximumlikelihood analysis of the 16S rRNA gene sequences and a transmission electron micrograph of cells of strain TRM $0175^{\top}$ are available as supplementary material with the online version of this paper.
Strain TRM $0175^{\mathrm{T}}$, which belongs to the genus Halomonas, was isolated from a soil sample from Lop Nur salt lake $\left(40^{\circ}\right.$ $23^{\prime} \mathrm{N} 90^{\circ} 18^{\prime} \mathrm{E} ; 778 \mathrm{~m}$ altitude) in Xinjiang Province, north-west China. The high salinity $(30.5 \%)$, low nutrient levels, dry climate and high UV intensity make it an extreme environment. A soil sample (approx. $100 \mathrm{~g}$ ) was collected from Lop Nur salt lake in autumn. The temperature and $\mathrm{pH}$ of the soil sample, measured with portable meters, were $16.2{ }^{\circ} \mathrm{C}$ and $\mathrm{pH} 7.4$, respectively. The sample was isolated on trypticase soy agar (TSA) containing $15 \%(\mathrm{w} / \mathrm{v}) \mathrm{NaCl}$ by using a tenfold dilution series method. The organism was grown and maintained at $37{ }^{\circ} \mathrm{C}$ on TSA containing $10 \%(\mathrm{w} / \mathrm{v}) \mathrm{NaCl}$.

Cell morphology and motility were examined by optical microscopy (Olympus BX40) and transmission electron microscopy (Philips CM200). For $\mathrm{NaCl}$ tolerance experiments, growth was studied at $37{ }^{\circ} \mathrm{C}$ in TSA containing 0 ,

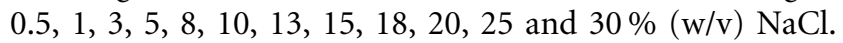
Growth was investigated on TSA containing $10 \%(\mathrm{w} / \mathrm{v})$ $\mathrm{NaCl}$ at $5-55{ }^{\circ} \mathrm{C}$ (at intervals of $5{ }^{\circ} \mathrm{C}$ ) and at $\mathrm{pH} 4-12$ (at 
$1 \mathrm{pH}$ unit intervals) using the following buffer systems: $\mathrm{pH} 4.0-5.0, \quad 0.1 \mathrm{M}$ citric acid/0.1 M sodium citrate; pH 6.0-8.0, $0.1 \mathrm{M} \mathrm{KH}_{2} \mathrm{PO}_{4} / 0.1 \mathrm{M} \mathrm{NaOH}$; pH 9.0-10.0, $0.1 \mathrm{M} \mathrm{NaHCO}_{3} / 0.1 \mathrm{M} \mathrm{Na}_{2} \mathrm{CO}_{3}$. Biochemical tests (on TSA containing $10 \% \mathrm{NaCl}$ ) and nutritional tests [in medium containing ( $\mathrm{l}^{-1}$ distilled water): $100 \mathrm{~g} \mathrm{NaCl}, 2 \mathrm{~g} \mathrm{KCl}, 0.2 \mathrm{~g}$ $\mathrm{MgSO}_{4} \cdot 7 \mathrm{H}_{2} \mathrm{O}, 1 \mathrm{~g} \mathrm{KNO}_{3}, 1 \mathrm{~g}\left(\mathrm{NH}_{4}\right)_{2} \mathrm{HPO}_{4}$ and $0.5 \mathrm{~g}$ $\left.\mathrm{KH}_{2} \mathrm{PO}_{4}\right]$ were carried out according to Mata et al. (2002). In addition, antimicrobial susceptibility tests were performed on TSA using antimicrobial compounds (BBL) as outlined by Mata et al. (2002). Detailed results are given in the species description.

Genomic DNA of strain TRM $0175^{\mathrm{T}}$ was extracted from cells grown on TSA containing $10 \% \mathrm{NaCl}$ for 3 days at $37^{\circ} \mathrm{C}$ and used as a template for subsequent PCR amplification. Reaction conditions and amplification protocols used were as described by Hezayen et al. (2002). The almost-complete $16 \mathrm{~S}$ rRNA gene sequence of strain TRM $0175^{\mathrm{T}}(1420 \mathrm{nt})$ was obtained and compared with available $16 \mathrm{~S}$ rRNA gene sequences in GenBank using BLAST searches (Altschul et al., 1990). The 16S rRNA gene sequence of strain TRM $0175^{\mathrm{T}}$ was aligned with those of available strains of Halomonas species obtained from GenBank. Phylogenetic trees were constructed by the neighbourjoining (Saitou \& Nei, 1987) and maximum-parsimony (Fitch, 1971) methods with the MEGA3 program package (Kumar et al., 2004) and by the maximum-likelihood method (Felsenstein, 1981) with the PHYLIP 3.6 program. Phylogenetic tree topologies were evaluated by the bootstrap resampling method of Felsenstein (1985) with 1000 replicates. Results indicated that strain TRM $0175^{\mathrm{T}}$ clustered within the genus Halomonas and exhibited the closest phylogenetic affinity (Fig. 1) and highest sequence similarity to Halomonas anticariensis $\mathrm{FP}^{-\mathrm{T}}$ (95.3\%). 16S rRNA gene sequence similarity values between strain TRM $0175^{\mathrm{T}}$ and strains of other Halomonas species were below $95 \%$. Phylogenetic trees based on maximum-parsimony and maximum-likelihood analysis of 16S rRNA gene sequences are shown in Supplementary Fig. S1 (available in IJSEM Online). The DNA G $+\mathrm{C}$ content of strain TRM $0175^{\mathrm{T}}$ was determined by using the HPLC method (Mesbah et al., 1989). The DNA G $+\mathrm{C}$ content of strain TRM $0175^{\mathrm{T}}(60.0 \mathrm{~mol} \%)$ was distinct from that of $H$. anticariensis $\mathrm{FP} 35^{\mathrm{T}}$, the most closely related type strain (61.4 mol\%; Martínez-Cánovas et al., 2004).

Menaquinones were extracted using the method of Collins et al. (1977) and analysed by HPLC (Groth et al., 1997). Cellular fatty acid composition was determined as described by Sasser (1990) using the Microbial Identification System (MIDI). The major ubiquinone of strain TRM $0175^{\mathrm{T}}$ was Q-9 (93\%); a small amount of Q-8 (7\%) was also present. The major fatty acids (greater than $1 \%)$ of strain TRM $0175^{\mathrm{T}}$ were $\mathrm{C}_{18: 1} \omega 7 c(39.6 \%), \mathrm{C}_{19: 0}$ cyclo $\omega 8 c(24.0 \%), \mathrm{C}_{16: 0}(12.3 \%), \mathrm{C}_{16: 1} \omega 7 c / \mathrm{C}_{16: 1} \omega 6 c$ $(7.4 \%), \mathrm{C}_{12: 0}(4.8 \%), \mathrm{C}_{17: 0}$ cyclo $(3.2 \%), \mathrm{C}_{12: 0} 3-\mathrm{OH}$ $(2.9 \%), \mathrm{C}_{18: 0}(2.1 \%), \mathrm{C}_{10: 0}(2.0 \%)$ and $\mathrm{C}_{17: 0}(1.8 \%)$. Differential characteristics and fatty acid compositions of

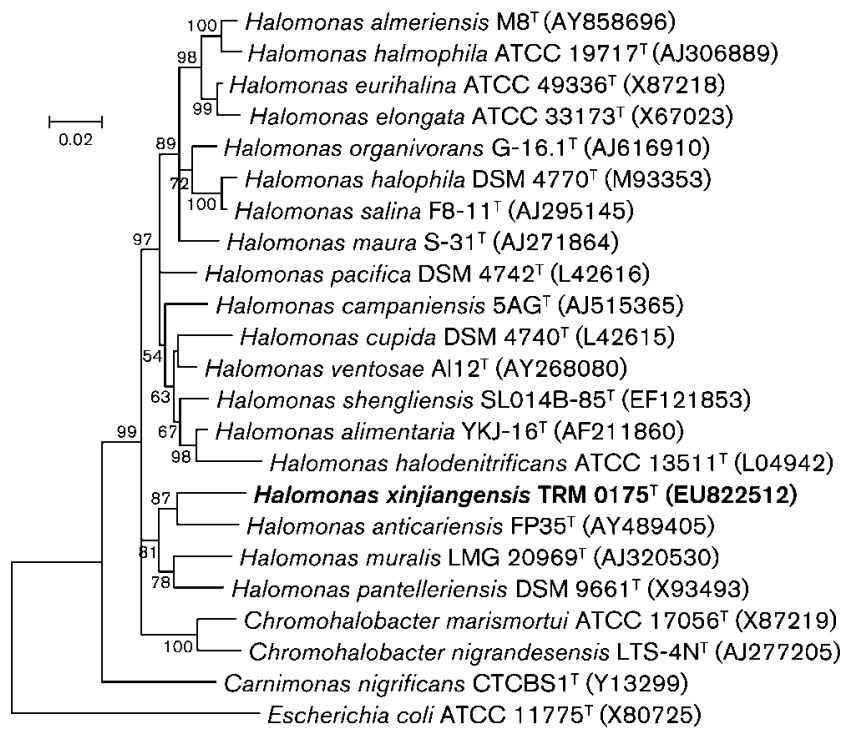

Fig. 1. Neighbour-joining tree based on 16S rRNA gene sequences showing the phylogenetic relationships of the novel isolate and related taxa. Bootstrap values are based on 1000 replicates; only values $>50 \%$ are shown. Bar, 0.02 substitutions per nucleotide position.

strain TRM $0175^{\mathrm{T}}$ and H. anticariensis $\mathrm{FP} 35^{\mathrm{T}}$ are shown in Tables 1 and 2.

Combined morphological, phenotypic and genotypic data indicate that the isolate represents a novel species in the genus Halomonas, for which the name Halomonas xinjiangensis sp. nov. is proposed.

\section{Description of Halomonas xinjiangensis sp. nov.}

Halomonas xinjiangensis (xin.ji.ang.en'sis. N.L. fem. adj. xinjiangensis pertaining to Xinjiang, a region of China, from where the type strain was isolated).

Cells are Gram-negative, aerobic, motile by means of peritrichous flagella and rod-shaped, approximately 1.2$2.0 \times 0.6-1.0 \mu \mathrm{m}$ in size (Supplementary Fig. S2). Colonies on TSA medium are 1-2 $\mathrm{mm}$ in diameter, smooth, circular and brown-orange after 5 days. Growth occurs at $15-50{ }^{\circ} \mathrm{C}$ and $\mathrm{pH}$ 6.0-9.0, with optimum growth at $37^{\circ} \mathrm{C}$ and $\mathrm{pH}$ 7.0. Grows in $0-20 \%(\mathrm{w} / \mathrm{v}) \mathrm{NaCl}$, with optimum growth at $10-13 \%(\mathrm{w} / \mathrm{v}) \mathrm{NaCl}$. Metabolism is respiratory with oxygen as terminal electron acceptor. Does not grow anaerobically in the presence of nitrate, nitrite or fumarate. Oxidase-negative and catalase-positive. Phosphatase is produced, but not exopolysaccharide or poly- $\beta$-hydroxyalkanoate. Nitrate is reduced to nitrite. Selenite is reduced. Aesculin and Tweens 20 and 80 are hydrolysed, but casein, DNA, gelatin, starch and urea are not. $\mathrm{H}_{2} \mathrm{~S}$ is formed from L-cysteine. Positive for gluconate oxidation. Negative for lysine decarboxylase, ornithine decarboxylase, phenylalanine deamination, indole production, the methyl 
Table 1. Differential characteristics of strain TRM $0175^{\top}$ and its closest relative $H$. anticariensis $\mathrm{FP} 35^{\top}$

Data for H. anticariensis $\mathrm{FP}_{3} 5^{\mathrm{T}}$ were taken from Martínez-Cánovas et al. (2004).

\begin{tabular}{|c|c|c|}
\hline Characteristic & TRM $0175^{\mathrm{T}}$ & $\begin{array}{l}\text { H. anticariensis } \\
{\text { FP } 35^{\mathrm{T}}}\end{array}$ \\
\hline Cell size $(\mu \mathrm{m})$ & $\begin{array}{r}1.20-2.00 \times \\
0.60-1.00\end{array}$ & $\begin{array}{r}3.00-3.50 \times \\
0.75-1.00\end{array}$ \\
\hline Exopolysaccharide production & - & + \\
\hline Oxidase & - & + \\
\hline Nitrate reduction & + & - \\
\hline $\mathrm{H}_{2} \mathrm{~S}$ production & + & - \\
\hline Temperature range $\left({ }^{\circ} \mathrm{C}\right)$ & $15-50$ & $20-45$ \\
\hline $\mathrm{NaCl}$ range $(\%, \mathrm{w} / \mathrm{v})$ & $0-20$ & $0.5-15$ \\
\hline $\mathrm{NaCl}$ optimum $(\%, \mathrm{w} / \mathrm{v})$ & $10-13$ & 7.5 \\
\hline \multicolumn{3}{|l|}{ Hydrolysis of: } \\
\hline Aesculin & + & - \\
\hline Tween 80 & + & - \\
\hline Urea & - & + \\
\hline \multicolumn{3}{|l|}{ Sole source of carbon and energy } \\
\hline L-Arabinose & - & + \\
\hline myo-Inositol & - & + \\
\hline D-Mannitol & - & + \\
\hline D-Galactose & + & - \\
\hline \multicolumn{3}{|l|}{$\begin{array}{l}\text { Sole source of carbon, nitrogen } \\
\text { and energy }\end{array}$} \\
\hline L-Alanine & - & + \\
\hline L-Histidine & - & + \\
\hline \multicolumn{3}{|l|}{ Acid production from: } \\
\hline L-Arabinose & + & - \\
\hline D-Ribose & + & - \\
\hline D-Xylose & + & - \\
\hline D-Galactose & + & - \\
\hline L-Rhamnose & + & - \\
\hline Cellobiose & + & - \\
\hline Maltose & + & - \\
\hline Trehalose & + & - \\
\hline D-Fucose & + & - \\
\hline \multicolumn{3}{|l|}{ Susceptible to: } \\
\hline Tobramycin & - & + \\
\hline Trimethoprim/sulfametoxazole & - & + \\
\hline Lipoquinone(s) & Q-9, Q-8* & Q-9 \\
\hline DNA G $+C$ content $(\mathrm{mol} \%)$ & 60.0 & 61.4 \\
\hline
\end{tabular}

${ }^{\star} 93 \%$ Q-9 and 7\% Q-8.

red and Voges-Proskauer tests, $o$-nitrophenyl $\beta$-D-galactopyranosidase and fermentation of glucose. Utilizes Lrhamnose, D-mannose, D-fructose, D-galactose, trehalose, aesculin, xanthine, L-asparagine, L-serine and hypoxanthine as sole sources of carbon, nitrogen (where appropriate) and energy, but not D-mannitol, maltose, D-sorbitol, cellobiose, D-ribose, D-xylose, myo-inositol, lactose, raffinose, Dsalicin, arabinose, xylitol, dulcitol, L-alanine, L-histidine, L-lysine or L-arginine. Acid is produced from D-ribose, D-
Table 2. Fatty acid contents of strain TRM $0175^{\top}$ and $H$. anticariensis $\mathrm{FP}^{\mathrm{T}}{ }^{\mathrm{T}}$

Data for $H$. anticariensis $\mathrm{FP}^{\mathrm{T}} 5^{\mathrm{T}}$ were taken from Martínez-Cánovas et al. (2004). Values are percentages of total fatty acids; fatty acids that account for less than $1.0 \%$ total fatty acids in both strains are not shown. NA, Not applicable/not reported.

\begin{tabular}{|lcc|}
\hline Fatty acid & TRM $^{\mathbf{0 1 7 5}}{ }^{\mathbf{T}}$ & H. anticariensis $\mathbf{F P 3 5}^{\mathbf{T}}$ \\
\hline $10: 0$ & 2.0 & 2.7 \\
$12: 0$ & 4.8 & 3.4 \\
$12: 03-\mathrm{OH}$ & 2.9 & 5.2 \\
$16: 0$ & 12.3 & 25.5 \\
$16: 1 \omega 7 c / 16: 1 \omega 6 c$ & 7.4 & $\mathrm{NA}$ \\
$16: 1 \omega 7 c / 15: 0$ iso $2-\mathrm{OH}$ & $\mathrm{NA}$ & 12.5 \\
$17: 0$ cyclo & 3.2 & $\mathrm{NA}$ \\
$17: 0$ & 1.8 & $\mathrm{NA}$ \\
$18: 0$ & 2.1 & $\mathrm{NA}$ \\
$18: 1 \omega 7 c$ & 39.6 & 47.6 \\
$19: 0$ cyclo $\omega 8 c$ & 24.0 & 1.1 \\
\hline
\end{tabular}

and L-arabinose, D-xylose, D-galactose, D-mannose, Lrhamnose, cellobiose, maltose, trehalose, D- and L-fucose. Acid is produced weakly from aesculin, but not from erythritol, D-adonitol, glycerol, L-xylose, D-fructose, Lsorbose, methyl $\beta$-D-xyloside, dulcitol, myo-inositol, Dmannitol, D-glucose, D-sorbitol, D-lactose, arbutin, salicin, methyl $\alpha$-D-mannoside, methyl $\alpha$-D-glucoside, $N$-acetylglucosamine, amygdalin, inulin, melezitose, raffinose, starch, glycogen, gentiobiose, xylitol, turanose, D-lyxose, D-tagatose or D- or L-arabitol. Susceptible to streptomycin $(10 \mu \mathrm{g})$, amoxicillin $(25 \mu \mathrm{g})$, chloramphenicol $(30 \mu \mathrm{g})$, cefoxitin $(30 \mu \mathrm{g})$, kanamycin $(30 \mu \mathrm{g})$, nalidixic acid $(30 \mu \mathrm{g})$, nitrofurantoin $(300 \mu \mathrm{g})$, ampicillin $(10 \mu \mathrm{g})$, sulfamide $(250 \mu \mathrm{g})$, cefotaxime $(30 \mu \mathrm{g})$, erythromycin $(15 \mu \mathrm{g})$, polymyxin B (300 IU), rifampicin $(30 \mu \mathrm{g})$ and carbenicillin $(100 \mu \mathrm{g})$, but not to tobramycin $(10 \mu \mathrm{g})$ or trimethoprim/ sulfametoxazole $(1.25 / 23.75 \mu \mathrm{g})$. The predominant ubiquinone is Q-9. The major fatty acids (greater than $5 \%$ ) are $\mathrm{C}_{18: 1} \omega 7 c, \mathrm{C}_{19: 0}$ cyclo $\omega 8 c, \mathrm{C}_{16: 0}$ and $\mathrm{C}_{16: 1} \omega 7 c / \mathrm{C}_{16: 1} \omega 6 c$.

The type strain is TRM $0175^{\mathrm{T}}$ (=CCTCC AB $208329^{\mathrm{T}}$ $=$ KCTC $22608^{\mathrm{T}}$ ), isolated from a hypersaline soil sample from Xinjiang Province, north-west China. The DNA $\mathrm{G}+\mathrm{C}$ content of the type strain is $60.0 \mathrm{~mol} \%$.

\section{Acknowledgements}

This research was supported by the National Natural Science Foundation of China (project no. 30660005), the Key Project for the Department of Science and Technology of the Ministry of Education of China (project no. 209145), the Scientific Research Foundation for the Returned Overseas Chinese Ministry of Personnel (project no. 610605), the Opening Project by the Key Laboratory of Protection and Utilization of Biological Resources in Tarim Basin of Xinjiang Production \& Construction Corps (project no. BR0803) and the Program of the Higher Education Institution of Xinjiang (project no. XJEDU2005G07). 


\section{References}

Altschul, S. F., Gish, W., Miller, W., Myers, E. W. \& Lipman, D. J. (1990). Basic local alignment search tool. J Mol Biol 215, 403-410.

Arahal, D. R., Castillo, A. M., Ludwig, W., Schleifer, K. H. \& Ventosa, A. (2002). Proposal of Cobetia marina gen. nov., comb. nov., within the family Halomonadaceae, to include the species Halomonas marina. Syst Appl Microbiol 25, 207-211.

Arahal, D. R., Vreeland, R. H., Litchfield, C. D., Mormile, M. R., Tindall, B. J., Oren, A., Bejar, V., Quesada, E. \& Ventosa, A. (2007). Recommended minimal standards for describing new taxa of the family Halomonadaceae. Int J Syst Evol Microbiol 57, 2436-2446.

Ben Ali Gam, Z., Abdelkafi, S., Casalot, L., Tholozan, J. L., Oueslati, R. \& Labat, M. (2007). Modicisalibacter tunisiensis gen. nov., sp. nov., an aerobic, moderately halophilic bacterium isolated from an oilfieldwater injection sample, and emended description of the family Halomonadaceae Franzmann et al. 1989 emend. Dobson and Franzmann 1996 emend. Ntougias et al. 2007. Int J Syst Evol Microbiol 57, 2307-2313.

Collins, M. D., Pirouz, T., Goodfellow, M. \& Minnikin, D. E. (1977). Distribution of menaquinones in actinomycetes and corynebacteria. J Gen Microbiol 100, 221-230.

Dobson, S. J. \& Franzmann, P. D. (1996). Unification of the genera Deleya (Baumann et al. 1983), Halomonas (Vreeland et al. 1980), and Halovibrio (Fendrich 1988) and the species Paracoccus halodenitrificans (Robinson and Gibbons 1952) into a single genus, Halomonas, and placement of the genus Zymobacter in the family Halomonadaceae. Int J Syst Bacteriol 46, 550-558.

Felsenstein, J. (1981). Evolutionary trees from DNA sequences: a maximum likelihood approach. J Mol Evol 17, 368-376.

Felsenstein, J. (1985). Confidence limits on phylogenies: an approach using the bootstrap. Evolution 39, 783-791.

Fitch, W. M. (1971). Toward defining the course of evolution: minimum change for a specific tree topology. Syst Zool 20, 406-416.

Franzmann, P. D., Wehmeyer, U. \& Stackebrandt, E. (1988). Halomonadaceae fam. nov., a new family of the class Proteobacteria to accommodate the genera Halomonas and Deleya. Syst Appl Microbiol 11, 16-19.

Garriga, M., Ehrmann, M. A., Arnau, J., Hugas, M. \& Vogel, R. F. (1998). Carnimonas nigrificans gen. nov., sp. nov., a bacterial causative agent for black spot formation on cured meat products. Int J Syst Bacteriol 48, 677-686.
Groth, I., Schumann, P., Rainey, F. A., Martin, K., Schuetze, B. \& Augsten, K. (1997). Demetria terragena gen. nov., sp. nov., a new genus of actinomycetes isolated from compost soil. Int J Syst Bacteriol 47, 1129-1133.

Hezayen, F. F., Tindall, B. J., Steinbüchel, A. \& Rehm, B. H. A. (2002). Characterization of a novel halophilic archaeon, Halobiforma haloterrestris gen. nov., sp. nov., and transfer of Natronobacterium nitratireducens to Halobiforma nitratireducens comb. nov. Int J Syst Evol Microbiol 52, 2271-2280.

Kumar, S., Tamura, K. \& Nei, M. (2004). MEGA3: integrated software for molecular evolutionary genetics analysis and sequence alignment. Brief Bioinform 5, 150-163.

Martínez-Cánovas, M. J., Béjar, V., Martínez-Checa, F. \& Quesada, E. (2004). Halomonas anticariensis sp. nov., from Fuente de Piedra, a saline-wetland wildfowl reserve in Málaga, southern Spain. Int J Syst Evol Microbiol 54, 1329-1332.

Mata, J. A., Martínez-Cánovas, M. J., Quesada, E. \& Béjar, V. (2002). A detailed phenotypic characterization of the type strain of Halomonas species. Syst Appl Microbiol 25, 360-375.

Mesbah, M., Premachandran, U. \& Whitman, W. B. (1989). Precise measurement of the $\mathrm{G}+\mathrm{C}$ content of deoxyribonucleic acid by highperformance liquid chromatography. Int J Syst Bacteriol 39, 159-167.

Ntougias, S., Zervakis, G. I. \& Fasseas, C. (2007). Halotalea alkalilenta gen. nov., sp. nov., a novel osmotolerant and alkalitolerant bacterium from alkaline olive mill wastes, and emended description of the family Halomonadaceae Franzmann et al. 1989, emend. Dobson and Franzmann 1996. Int J Syst Evol Microbiol 57, 1975-1983.

Okamoto, T., Taguchi, H., Nakamura, K., Ikenaga, H., Kuraishi, H. \& Yamasato, K. (1993). Zymobacter palmae gen. nov., sp. nov., a new ethanol-fermenting peritrichous bacterium isolated from palm sap. Arch Microbiol 160, 333-337.

Saitou, N. \& Nei, M. (1987). The neighbor-joining method: a new method for reconstructing phylogenetic trees. Mol Biol Evol 4, 406-425.

Sasser, M. (1990). Identification of bacteria by gas chromatography of cellular fatty acids, MIDI Technical Note 101. Newark, DE: MIDI Inc.

Ventosa, A., Gutierrez, M. C., Garcia, M. T. \& Ruiz-Berraquero, F. (1989). Classification of "Chromobacterium marismortui" in a new genus, Chromohalobacter gen. nov., as Chromohalobacter marismortui comb. nov., nom. rev. Int J Syst Bacteriol 39, 382-386.

Vreeland, R. H., Litchfield, C. D., Martin, E. L. \& Elliot, E. (1980). Halomonas elongata, a new genus and species of extremely salttolerant bacteria. Int J Syst Bacteriol 30, 485-495. 